\title{
An uncommon hip pain
}

\author{
Sandesh Madi, Vivek Pandey, Kiran Acharya, Vikash Kumar
}

Department of Orthopaedics, Kasturba Medical College, Manipal, Karnataka, India

\section{Correspondence to}

Dr Sandesh Madi, sandesh.madi@gmail.com

Accepted 27 July 2017

\section{DESCRIPTION}

A 55-year-old man with a medical history of hypertension and dyslipidaemia, presented to our Hip clinic with non-traumatic left hip pain of five months duration. The pain was insidious in onset and gradually progressive. The pain aggravated on, prolonged sitting or squatting, and relieved with rest. There was no history of any constitutional symptoms. The gait of the patient was essentially normal. There was tenderness over the anterior joint line and mild pain on flexion and internal rotation of the hip. There was no limb length discrepancy or wasting of the adjacent muscles. Distal neurovascular examination was normal.

A plain X-ray of the pelvis showed an ill-defined expansile lytic lesion involving the left superior pubic ramus with sclerotic margins and few internal septations (figure 1). Further $\mathrm{CT}$ and MRI scans defined the extent of the lesion (figure 2A,B,C and 3A,B,C). Through a Pfannenstiel incision, the lesion in the left superior pubic ramus was approached and a biopsy was undertaken. Histopathology and immunohistochemistry studies diagnosed the lesion as Plasmacytoma (figure 4). Myeloma profile (a panel of serological tests and bone marrow studies to evaluate patients with suspected multiple myeloma) was negative and bone scan revealed no other site involvement (table 1). With the diagnosis of Solitary Bone Plasmacytoma (SBP), the patient is currently undergoing Radiotherapy. A Radiotherapy regime: 2 Gy per day for 5 days is planned for 6 weeks using $3 \mathrm{D}$ Conformal Radiotherapy. Periodic serological investigations and immunofixation studies will

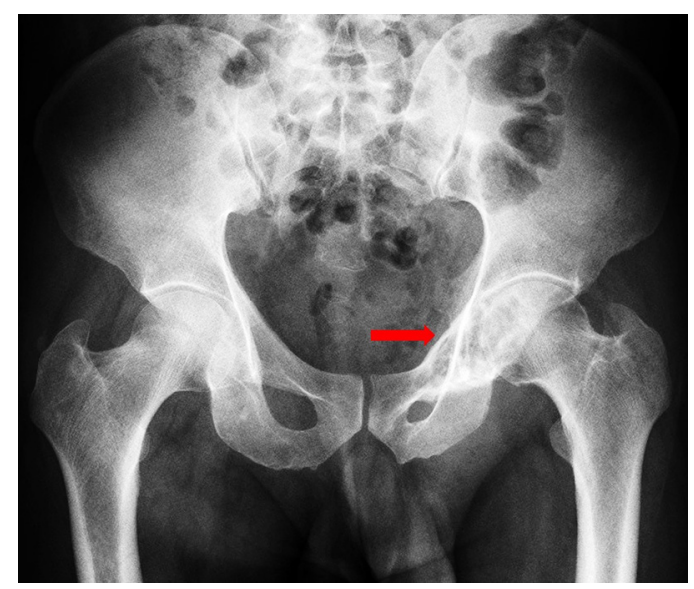

Figure 1 Plain X-ray of the pelvis showing an illdefined expansile lytic lesion with sclerotic margins involving the left superior pubic ramus (red arrow). There is no evidence of any periosteal reaction. The rest of the bones are normal in density and alignment. Joint spaces and articular surfaces are normal.

be performed to determine the disappearance of serum $\mathrm{M}$ protein. Further, imaging studies (eg, fluorodeoxyglucose PET scans, for any regression of metabolic activity) will be used to monitor the response to treatment.

Localised plasma cell dyscrasia is divided into two types based on the location of the lesion: SBP (predominantly involving the axial skeleton) and ExtraMedullary Plasmacytoma (EMP). Both these lesions are differentiated fromMyeloma by lack of CRAB features (increased calcium, renal insufficiency, anaemia or multiple bone

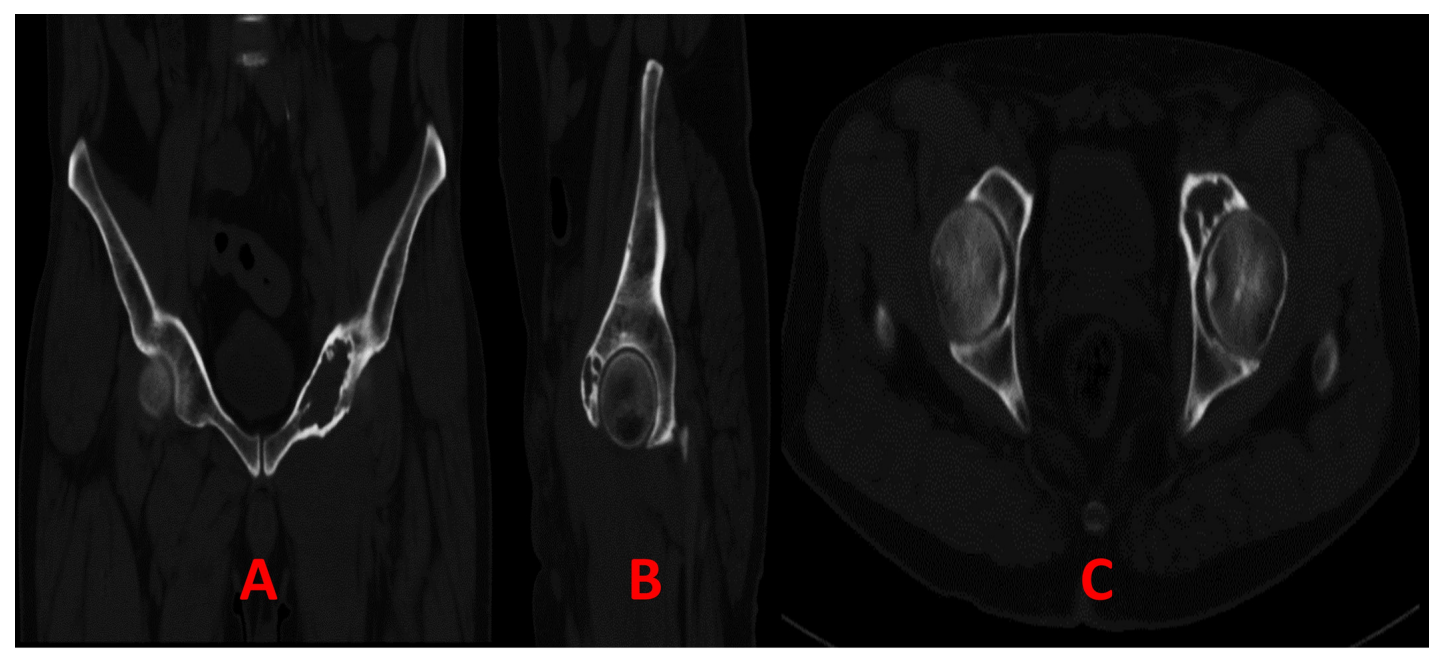

Figure 2 CT scan showed lytic expansile lesion $(3.9 \mathrm{~cm} \times 2.9 \mathrm{~cm})$ with sclerotic margin (A: coronal; B: sagittal; and C: axial sections). 


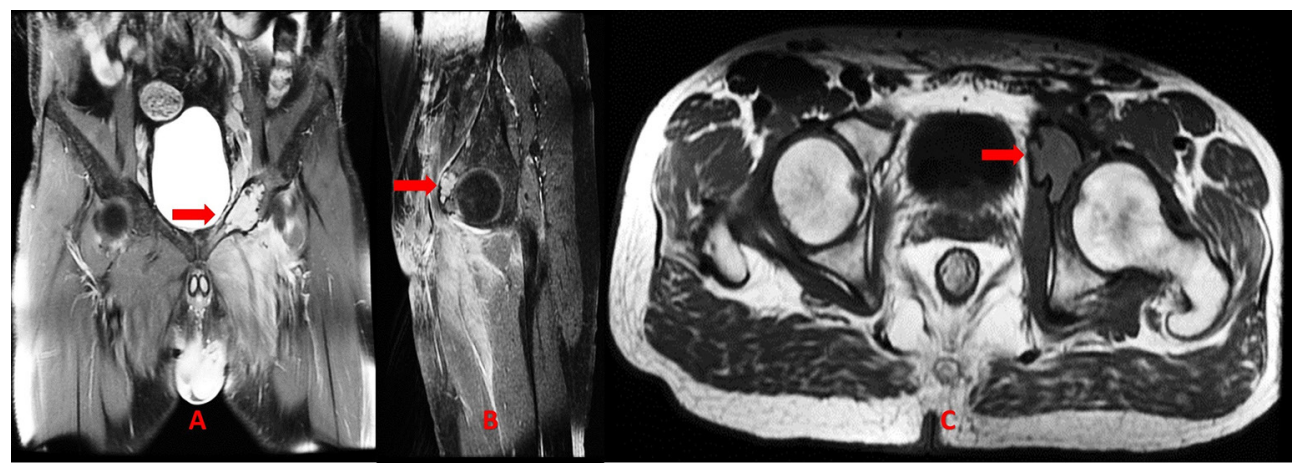

Figure 3 MRI scan: An altered signal intensity lesion (red arrow) noted involvement of the left superior pubic ramus, roof and anterior column and anterior wall of acetabulum causing expansion of the bone with minimal postcontrast enhancement (A: coronal (T2W); B: sagittal (T2W); and C: axial (T1W) sections).

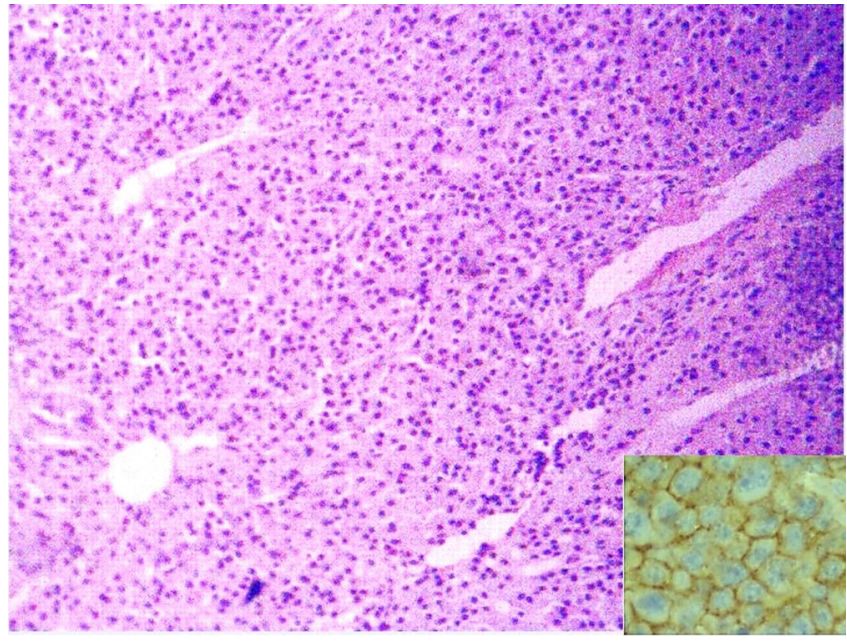

Figure 4 Histopathology (H\&E stain; low power) section showing a tumour composed of sheets of plasma cells, scattered plasmablasts along with focal aggregates of lymphocytes interspersed with congested blood vessels (Inset: CD138-positive).

lesions). SBP is a rare plasma cell neoplasm that targets areas of the marrow with most active haematopoiesis; the order of frequency of the location in which they are typically found is the vertebrae (thoracic >lumbar/cervical), ribs, skull, pelvis, femur, clavicle and scapula. ${ }^{1}$ To our knowledge, SBP involving the pubic ramus and acetabulum has not been previously reported. The clinical presentation is usually pain that is believed to occur from the ongoing bone destruction. Sometimes it can also be an incidental finding in another radiological workup. In imaging studies, it appears as a lytic lesion and demands differentiation from other common lytic lesions specific to age and location. In case of clinical suspicion, the International Myeloma Working Group criteria (Myeloma profile + skeletal survey + histopathology) to diagnose SBP should be considered. ${ }^{2}$ In the index case, due to clinical presentation and endemic nature, tuberculosis was also considered in the differential diagnosis. Adverse prognostic factors include a lesion size of minimum $5 \mathrm{~cm}$, age ( $>40$ years), spine lesions, radiotherapy dose ( $<40 \mathrm{~Gy}$ ), high $\mathrm{M}$ protein levels, existence of light chains and persistence of $\mathrm{M}$ protein after treatment. ${ }^{3}$ Further, a close follow-up is warranted to look out for local recurrence or conversion to a full blown Myeloma. SBP has a significantly higher risk

\begin{tabular}{|c|c|}
\hline Investigation & Reports (reference values) \\
\hline Haemoglobin & $14.3 \mathrm{~g} / \mathrm{dL}(13-17 \mathrm{~g} / \mathrm{dL})$ \\
\hline TLC & $6.2 \times 10^{9} / L\left(4-11 \times 10^{9} / L\right)$ \\
\hline \multirow[t]{2}{*}{ DLC } & Lymphocytes—36 \% \\
\hline & Neutrophils-53 \% \\
\hline ESR & $42 \mathrm{~mm} /$ hour (0-20 mm/hour) \\
\hline CRP & $3.5 \mathrm{mg} / \mathrm{L}(0-5 \mathrm{mg} / \mathrm{L})$ \\
\hline Serum urea & $13 \mathrm{mg} / \mathrm{dL}(10-40 \mathrm{mg} / \mathrm{dL})$ \\
\hline Serum creatinine & $0.8 \mathrm{mg} / \mathrm{dL}(0.6-1.4 \mathrm{mg} / \mathrm{dL})$ \\
\hline Total serum protein & $6.80 \mathrm{gm} / \mathrm{dL}(6-8 \mathrm{gm} / \mathrm{dL})$ \\
\hline Serum albumin & $4.50 \mathrm{gm} / \mathrm{dL}(3.5-5 \mathrm{gm} / \mathrm{dL})$ \\
\hline Serum globulin & $2.30 \mathrm{mg} / \mathrm{dL}(2.0-3.5 \mathrm{mg} / \mathrm{dL})$ \\
\hline Serum ALP & $54 \mathrm{U} / \mathrm{L}(50-140 \mathrm{U} / \mathrm{L})$ \\
\hline Serum calcium & $9.1 \mathrm{mg} / \mathrm{dL}(8.9-10.3 \mathrm{mg} / \mathrm{dL})$ \\
\hline PCR (nested) for TB & Negative \\
\hline Tissue biopsy & Tumour composed of sheets of plasma cells \\
\hline Protein electrophoresis & Raised $\gamma$ globulins \\
\hline Bone marrow aspiration & No evidence of myeloma/metastasis \\
\hline Bone marrow biopsy & No abnormal plasma cells seen \\
\hline Skeletal survey & No lytic lesions detected elsewhere \\
\hline Light chain analysis & $\kappa / \lambda$ ratio: 1.5 (normal) \\
\hline Immunofixation & Monoclonal (IgG) gammopathy \\
\hline FDG PET scan & FDG uptake noted only in the lytic lesion \\
\hline
\end{tabular}

ALP, alkaline phosphatase; CRP, C reactive protein; DLC, differential leucocyte count; ESR, erythrocyte sedimentation rate; FDG, fluorodeoxyglucose; PET, positron emission tomography; TB, tuberculosis; TLC, total leucocyte count.

(compared with EMP) for progression to Myeloma at a rate of $65 \%-84 \%$ in 10 years and $65 \%-100 \%$ in 15 years. ${ }^{3}$ Most series report overall survival (10-year rate) in the 49\%-68\% range. $^{3}$

\section{Learning points}

- This is perhaps the first case to be reported on Solitary Bone Plasmacytoma (SBP) arising from the superior pubic ramus and adjacent anterior acetabular wall.

- Both radiologists as well as clinicians must be aware that SBP arising in the superior pubic ramus and acetabulum is an extremely rare cause of hip pain and needs to be included in the differential diagnosis for the lytic lesions in the pelvis. 
Contributors SM: Drafting, data collection, revision. VP: Drafting, revision, final approval. KA: Drafting, revision, final approval. VK: Drafting, data collection, revision.

Competing interests None declared.

\section{Patient consent Obtained.}

Provenance and peer review Not commissioned; externally peer reviewed.

(c) BMJ Publishing Group Ltd (unless otherwise stated in the text of the article) 2017. All rights reserved. No commercial use is permitted unless otherwise expressly granted.

\section{REFERENCES}

1 Jaffe ES, Harris NL, Stein H, Vardiman JW. eds. World Health Organization classification of tumours. Pathology and genetics of tumours of the haematopoietic and lymphoid tissues. Geneva: WHO, 2001.

2 International Myeloma Working Group. Criteria for the classification of monoclonal gammopathies, multiple myeloma and related disorders: a report of the International myeloma Working Group. Br J Haematol 2003;121:749.

3 Kilciksiz S, Karakoyun-Celik 0, Agaoglu FY, et al. A review for solitary plasmacytoma of bone and extramedullary plasmacytoma. ScientificWorldJournal 2012;2012:1-6.

Copyright 2017 BMJ Publishing Group. All rights reserved. For permission to reuse any of this content visit http://group.bmj.com/group/rights-licensing/permissions.

BMJ Case Report Fellows may re-use this article for personal use and teaching without any further permission.

Become a Fellow of BMJ Case Reports today and you can:

- Submit as many cases as you like

Enjoy fast sympathetic peer review and rapid publication of accepted articles

- Access all the published articles

- Re-use any of the published material for personal use and teaching without further permission

For information on Institutional Fellowships contact consortiasales@bmjgroup.com

Visit casereports.bmj.com for more articles like this and to become a Fellow 